\title{
Efikasi Diri Bahasa Inggris sebagai Mediator antara Orientasi Tujuan Penguasaan dan Keterikatan Siswa Belajar Bahasa Inggris
}

\author{
Andrielina Firdausih ${ }^{1} \mathcal{E}$ Bhina Patria ${ }^{2}$ \\ Fakultas Psikologi Universitas Gadjah Mada
}

\begin{abstract}
English Self-efficacy is a self-confidence in English proficiency which is important to student behaviour on learning process. This study aims to investigated the role of english self efficacy in mediating the relationship between mastery goal orientation and student engagement on learning English. The method was quantitative using survey approach with 173 subjects. The subject was 173 students of $10^{\text {th }}$ and $11^{\text {st }}$ grade in SMA Negeri 9 Yogyakarta in 2016/2017 selected by purposive sampling technique. The Morgan-Jinks Student Efficacy State modification scale, student engagement modification scale, and mastery goal orientation scale were used in this study. The result showed that English self-efficacy was partially mediated. The mastery goal orientation directly had positive role to the student engagement $(B=0.468 ; p<0.001)$. The mastery goal orientation had positive role to the student engagement on learning English with self-efficacy as mediator $\left(B^{\prime}=0.369 ; p<0.001\right)$, English self-efficacy on boys were higher than girls.
\end{abstract}

Keywords: english self-efficacy; mastery goal orientation; student engagement

\begin{abstract}
Abstrak. Efikasi diri Bahasa Inggris merupakan keyakinan diri terhadap kemampuan bahasa Inggris yang berperan penting terhadap perilaku siswa pada proses pembelajaran. Penelitian ini bertujuan untuk melihat peran efikasi diri bahasa Inggris memediasi hubungan antara orientasi tujuan penguasaan dan keterikatan siswa belajar bahasa Inggris. Metode penelitian yang digunakan adalah kuantitatif dengan pendekatan survey terhadap 173 subjek penelitian. Subjek penelitian merupakan siswa kelas X dan XI SMA Negeri 9 Yogyakarta tahun ajaran 2016/2017 melalui teknik purposive sampling. Pengumpulan data menggunakan modifikasi skala The Morgan-jinks Student Efficacy Scale, modifikasi skala keterikatan siswa, dan skala orientasi tujuan penguasaan. Hasil penelitian menunjukan efikasi diri bahasa Inggris memediasi secara parsial yaitu orientasi tujuan penguasaan secara langsung berperan positif terhadap keterikatan siswa $(B=0,468$ dan $p<0,001)$; orientasi tujuan penguasaan berperan positif terhadap keterikatan siswa belajar bahasa Inggris saat dimediasi oleh efikasi diri $(B=0,369$ dan $p<0,001)$, Efikasi diri bahasa Inggris laki-laki lebih tinggi dibandingkan perempuan.
\end{abstract}

Kata kunci : efikasi diri bahasa Inggris; keterikatan siswa; orientasi tujuan penguasaan

Kemampuan kecakapan berbahasa Inggris negara Indonesia perlu ditingkatkan. Hal tersebut dikarenakan kemampuan kecapa-

\footnotetext{
${ }^{1}$ Korespondensi mengenai isi artikel ini dapat

dilakukan melalui andrielina.firdausih@mail.ugm.ac.id

2 atau melalui patria@ugm.ac.id
}

kan bahasa Inggris negara Indonesia berada pada kategori menengah. Hasil penelitian survei online EF (Education First) EPI (English 
Proficiency Index) 2016 dengan jumlah subjek penelitian 950.000 dari 72 negara yang ratarata berusia 28 tahun, menunjukkan bahwa Indonesia memiliki urutan kecakapan berbahasa Inggris di bawah negara-negara tetangga pada tingkat asia (EF EPI, 2016). Persentase indeks kecakapan bahasa Inggris EF EPI negara Indonesia yaitu 52,94\% dari persentase kecakapan tertinggi di tingkat asia pada negara Singapura yaitu $63,52 \%$. Bahasa Inggris pada negara-negara asia digunakan dalam perdagangan, bisnis internasional, bidang akademis, dan manufaktur. Kecakapan bahasa Inggris suatu negara akan berdampak pada penerimaan inovasi negara tersebut secara global (EF EPI, 2016). Sehingga penting bagi negara Indonesia untuk meningkatkan kecakapan berbahasa Inggris.

Sekolah merupakan salah satu tempat yang berperan untuk perkembangan kemampuan bahasa Inggris siswa (Baroody, Rimm-Kaufman, Larsen, \& Curby, 2016). Hal ini ditunjukkan dengan ditetapkannya bahasa Inggris sebagai salah satu mata pelajaran yang wajib diajarkan di Sekolah Menengah Pertama (SMP) dan Sekolah Menengah Atas (SMA) (Panjaitan, 2013). Sekolah juga dapat berupaya dengan menyiapkan pengajaran melalui beberapa pendekatan, seperti hasil penelitian pada sekolah SMA 14 dan 21 Medan yang menunjukkan peningkatkan kemampuan berbicara bahasa Inggris dengan pendekatan pembelajaran kontekstual (Simbolon, 2014).

Sekolah dapat mengetahui kemampuan siswa yang dilihat berdasar lingkup nasional dengan melihat nilai ujian nasional (UN) (Safari, 2015). Hasil UN oleh tim penyusun laporan Badan Penelitian dan Pengembangan Kementrian Pendidikan dan Kebudayaan (Balitbang Kemendibud) 2014, menunjukkan daya serap mata pelajaran bahasa Inggris UN 2014/2015 siswa Indonesia berada di bawah standard kriteria ketuntasan minimal (KKM). Daya serap mata pelajaran bahasa Inggris tidak mencapai standar KKM 70\% (Rahmawati, et al., 2014). Daya serap mata pelajaran bahasa Inggris pada siswa SMA IPA adalah 64,33\% dan daya serap mata pelajaran bahasa Inggris pada siswa IPS adalah 57,48\%.

Belajar bahasa Inggris sebagai bahasa asing tidak lepas dari kesulitan dan hambatan. Siswa menganggap keterampilan speaking paling sulit dikuasai karena kurangnya kosakata dalam bahasa Inggris, sulit untuk menghafal, takut salah mengucapkan, takut ditertawakan teman, dan rendahnya pengetahuan grammar. Selanjutnya kesulitan keterampilan listening atau kesulitan mendengar video yang menggunakan bahasa Inggris karena kurangnya kosakata sehingga kesulitan memahami makna dari kata yang disampaikan. Kesulitan keterampilan writting karena keterampilan ini memerlukan proses yang komplek yaitu dengan diawali dengan penyusunan kerangka paragraf, pembuatan paragraf, pengecekkan ketetapan penulisan, pengecekan relevansi isi, dan mempublikasikan tulisan. Kesulitan keterampilan reading merupakan kesulitan yang paling rendah dirasakan karena ketertarikan pada kegiatan membaca, sehingga mudah memahami bacaan meski bacaan berbahasa Inggris (Megawati, 2016).

Sikap pasif pada saat pembelajaran merupakan salah satu karakteritik siswa Indonesia dalam proses pembelajaran (Nichols, 2014). Sebuah penilitian mengenai strategi untuk memotivasi siswa dalam belajar bahasa Inggris dilakukan oleh Nichols (2014). Penilitian dilakukan pada 62 siswa SMA yang berusia16 dan 17 tahun di International Christian School Jakarta. Hasil penelitian menunjukkan rendahnya keterikatan siswa ditunjukkan pada jumlah menit partisipasi siswa dalam kuis membaca yaitu 33 menit dari 137 menit proses pembelajaran berlangsung. 
Keterikatan siswa merupakan hal yang penting dalam proses pembelajaran. Hal ini dikarenakan keterikatan siswa berkaitan dengan keberhasilan pada proses belajar pembelajaran yang menjadikan siswa untuk mampu beradaptasi dengan lingkungan kelas (Christenson, Reschly, \& Wylie, 2012). Siswa yang memiliki keterikatan pada proses pembelajaran mampu bekerja sama, belajar secara kooperatif dan kolaboratif, serta memiliki insiatif untuk memahami materi dengan cara mempraktikannya (Abas, 2015). Sebuah penelitian dilakukan pada mahasiswa Universitas Muhammadiyah Sidoarjo prodi PGSD semester 2A1 dan 2A3 pada mata kuliah bahasa Inggris, menunjukkan hasil penelitian bahwa mahasiswa yang aktif berpartisipasi dikelas memiliki kepercayaan diri dan melakukan pengucapan bahasa Inggris mendekati benar (Megawati, 2016).

Setiap siswa memiliki orientasi tujuan yang berbeda-beda dalam terlibat pada sebuah proses pembelajaran (Shin, Lee, \& Seo, 2017). Siswa yang memiliki orientasi tujuan penguasaan (mastery goal) akan lebih terikat dalam mengikuti sebuah proses belajar. Hal ini dikarenakan Siswa dengan orientasi tujuan penguasaan (mastery goal) akan lebih mampu bertahan lebih lama, bekerja lebih keras, dan memiliki keterikatan emosi untuk menyelesaikan tugas (Mih, Mih, \& Dragos, 2015).

Efikasi diri siswa juga berperan terhadap peningkatan keterikatan siswa di kelas. Hal tersebut diperkuat dengan ungkapan Mahyudin et al. (2006) bahwa efikasi diri siswa yang tinggi akan menjadikan siswa memiliki kinerja yang baik pada proses pembelajaran bahasa Inggris. Efikasi diri merupakan hal penting bagi keterikatan siswa dalam proses belajar dan menjadi penyalur terbentuknya keterikatan perilaku, kogintif, dan motivasi siswa di dalam kelas (Linnenbrink \& Pintrich, 2003). Salah satu permasalahan siswa Indonesia dalam belajar bahasa
Inggris adalah keyakinan diri siswa akan kemampuan untuk berbicara menggunakan bahasa Inggris, sehingga menjadikan siswa pasif, takut, dan malu untuk berbicara menggunakan bahasa Inggris (Exley, 2005). Sebuah penelitian di Indonesia yang dilakukan oleh Marcelinno (2008) pada 258 siswa SMA dari enam kelas, menunjukkan bahwa siswa pasif saat berada di kelas bahasa Inggis (Marcellino, 2008).

Efikasi diri penting bagi hubungan antara keterikatan siswa dan orientasi tujuan penguasaan. Hal ini seperti yang diungkapkan oleh Bandura (1997), bahwa dapat dimiliki oleh siswa dengan orientasi tujuan penguasaan yang menjadikan siswa terikat pada pembelajaran (Bandura, 1986). Efikasi diri menentukkan keterikatan siswa pada tugas aktivitas di kelas yaitu ditunjukkan dengan seberapa besar usaha yang dilakukan siswa, seberapa lama siswa bertahan terhadap rintangan, dan seberapa tangguh siswa menghadapi situasi buruk (Pajares, 2002).

Beberapa penelitian lainya juga menyatakan bahwa efikasi diri memperantarai hubungan antara orientasi tujuan penguasaan dan keterikatan siswa. Hasil penelitian oleh Hsieh, Sullivan, dan Guerra (2007) menunjukkan bahwa efikasi diri pada siswa yang berorientasi tujuan penguasaan menjadikan siswa lebih terikat pada proses pembelajaran. Hasil penelitian yang dilakukan oleh Zare, Rastegar, dan Hosseini (2011) dengan 323 subjek di Universitas Payame Noor menunjukkan bahwa efikasi diri statistik memediasi hubungan antara orientasi tujuan penguasaan dan prestasi akademik.

Penulis menyimpulkan bahwa terdapat peran efikasi diri bahasa Inggris dalam memperantarai hubungan antara orientasi tujuan penguasaan dan keterikatan siswa belajar bahasa Inggris. Oleh karenanya, penelitian ini bertujuan untuk mengetahui apakah efikasi diri bahasa Inggris dapat memperantarai hubungan antara orientasi 
tujuan penguasaan dan keterikatan siswa belajar bahasa Inggris.

\section{Metode}

\section{Identifikasi Variabel}

Variabel yang digunakan pada penelitian ini adalah keterikatan siswa belajar bahasa Inggris.sebagai variabel tergantung, orientasi tujuan penguasaan sebagai variabel bebas, dan efikasi diri bahasa Inggris sebagai variabel mediator.

\section{Subjek Penelitian}

Subjek dalam penelitian ini adalah 173 siswa kelas X dan XI SMA Negeri 9 Yogyakarta yang terdiri 64 subjek dari kelas X dan 109 dari kelas XI. Subjek penelitian memiliki rentang usia 14 sampai 17 tahun. Subjek penelitian dengan jurusan IPA (Ilmu Pengetahuan Alam) lebih dominan (128) dibandingkan dengan subjek dari jurusan IPS (Ilmu Pengatuhan Sosial) (45). Subjek lakilaki berjumlah 42 dan perempuan berjumlah 131. Penentuan subjek penelitian dengan menggunakan teknik pursposive.

\section{Instrumen Penelitian}

Pengumpulan data pada penelitian menggunakan skala penelitian yaitu skala orientasi tujuan penguasaan, skala keterikatan siswa belajar bahasa Inggris, dan skala efikasi bahasa Inggris. Skala orientasi tujuan penguasaan disusun berdasarkan karakteristik pendekatan teori oleh Ames dan Acher (1988) dengan nilai reliabitas 0,789 (33 aitem). Skala keterikatan siswa belajar bahasa Inggris merupakan modifi-kasi skala yang disusun oleh Reeve dan Tseng (2011) dengan nilai reliabilitas 0,815 (21 aitem). Skala efikasi diri bahasa Inggris merupakan modifikasi The Morgan-Jinks Students Efficacy Scale (MJSES) dengan nilai relibitas 0,756 (21 aitem).

\section{Analisis Data}

Data dianalisis dengan analisis regresi menggunakan variabel mediator (efikasi diri bahasa Inggris) dan uji independent sample Ttest yang menggunakan SPSS for windows. Peneliti melakukan uji asumsi sebelum analisis data dilakukan, yaitu meliputi uji normalitas, uji multikolinearitas, dan uji linearitas.

\section{Hasil}

Kategorisasi data menunjukkan bahwa orientasi tujuan penguasaan, efikasi diri bahasa Inggris, dan keterikatan siswa belajar bahasa Inggris cenderung tinggi. Hal ini ditunjukkan pada hasil penelitian yaitu lebih dari separuh $(65,9 \%)$ subjek penelitian berorientasi tujuan penguasaan dengan kategori tinggi. Efikasi diri bahasa Inggris dominan $(46,8 \%)$ berada pada kategorisasi tinggi dan subjek penelitian dengan efikasi diri bahasa Inggris kategorisasi sedang yaitu $(45,7 \%)$. Lebih dari separuh $(60,7 \%)$ subjek penelitian memiliki kategori keterikatan siswa belajar bahasa Inggris yang tinggi.

Uji asumsi dilakukan sebelum uji hipotesis, yaitu meliputi uji normalitas, uji multikolinearitas, dan uji linearitas. Uji normalitas dengan Kolmogorov-smirnov menunjukkan bahwa distribusi data penelitian bersifat normal setelah dilakukan remove the case (menghapus data outlier). Hasil uji multikolinearitas menunjukkan tidak terjadinya kolinearitas antar variabel prediktor dalam penelitian. Kesimpulan ini didapat dengan melihat nilai tolerance sebesar 0.864 . Uji lineritas menunjukkan hasil bahwa terdapat hubungan linier.

Hasil analisis regresi uji mediasi pada penelitian dijelaskan pada Tabel 1 yang menunjukkan hasil mediasi variabel efikasi diri bahasa Inggris antara peran orientasi tujuan penguasaan dan keterikatan siswa 
Tabel 1

Rangkuman analisis regresi uji mediasi

\begin{tabular}{llllll}
\hline \multirow{2}{*}{ Jalur } & \multicolumn{2}{c}{ Regresi } & B & Sig & $\mathrm{R}^{2}$ \\
\cline { 2 - 3 } & $\begin{array}{c}\text { Variabel } \\
\text { independen }\end{array}$ & $\begin{array}{c}\text { Variabel } \\
\text { dependen }\end{array}$ & & & \\
\hline$a$ & OTP & ED & 0,308 & 0,000 & 0,136 \\
$b$ & ED & KS & 0,320 & 0,000 & 0,159 \\
$c$ & OTP & KS & 0,468 & 0,000 & 0,246 \\
$c^{\prime}$ & OTP & KS & 0,369 & 0,000 & 0,183 \\
& ED & & & & \\
\hline
\end{tabular}

Keterangan : OTP (Orientasi Tujuan Penguasaan); ED (Efikasi Diri); KS (Keterikatan Siswa)

belajar bahasa Inggris. Berikut penjabaran hasil analisis regresi uji mediasi.

Hasil analasis regresi Tabel 1 menunjukkan terpenuhinya Jalur c yaitu orientasi tujuan penguasaan berperan terhadap keterikatan siswa belajar bahasa Inggris. Hasil analisis regresi menunjukkan Beta $=0,468$ dan $p<0,05$. Hal ini membuktikan terpenuhinya syarat kondisi jalur $c$. Orientasi tujuan penguasaan berperan terhadap efikasi diri bahasa Inggris dengan Beta $=0,308$ dan $p<0,05$. Hal ini membuktikan terpenuhinya syarat kondisi jalur a. Efikasi diri bahasa Inggris berperan terhadap keterikatan siswa belajar bahasa Inggris (Beta $=0,320$ dan $\mathrm{p}<0,05$ ). Hal ini membuktikan terpenuhinya syarat kondisi jalur $b$, dan Jalur $c^{\prime}$ menunjukkan hasil analis nilai Beta $=0,369$ dan $p<0,01$. Hal ini menunjukan bahwa kondisi jalur $\mathrm{c}^{\prime}$ tidak terpenuhi. Kondisi tersebut menurut Baron dan Kenny (1986) merupakan bentuk mediasi parsial yaitu jalur $a, b, c$, dan $c^{\prime}$ signifikan. Uji tambahan menunjukkan bahwa efikasi diri bahasa Inggris laki-laki $(7,924)$ dan perempuan $(7,745)$.

\section{Diskusi}

Hasil penelitian menunjukkan orientasi tujuan penguasan terbukti berperan positif terhadap efikasi diri bahasa Inggris. Hal tersebut dapat dimaknai bahwa orientasi tujuan penguasaan memunculkan efikasi diri. Hal ini dapat disebabkan karena fokus siswa yang memiliki orientasi tujuan penguasaan yaitu penguasaan kemampuan dengan menghargai setiap pencapaian prestasi yang diperoleh dari bentuk usaha dan menganggap kegagalan sebagai proses pembelajaran, sehingga menjadikan siswa merasa yakin dan bersemangat untuk mampu menguasai materi pelajaran (Woolfolk, 2008).

Hal serupa juga diungkapkan oleh Pintrich dan Schunk (1996) bahwa orientasi tujuan penguasaan memunculkan efikasi diri siswa (Pintrich dan Schunk, 1996). Sebuah hasil penelitan oleh Gerhardt dan Brown (2006) menunjukkan hasil penelitian yang sama yaitu orientasi tujuan penguasaan tinggi menunjukkan efikasi diri yang tinggi. Hal tersebut dikarenakan orientasi tujuan penguasaan menjadikan siswa lebih meyakini akan kesuksesan di masa depan, sehingga menjadikan siswa lebih berusaha keras (Gerhardt \& Brown, 2006)

Hasil penelitian menunjukkan efikasi diri bahasa Inggris berperan positif terhadap keterikatan siswa belajar bahasa Inggris. Hal ini dikarenakan efikasi diri menjadikan siswa memiliki keyakinan akan hasil pembelajaran yang baik dan menjadikan siswa menghargai proses pembelajaran (Schunk \& Mullen, 2012). Siswa dengan efikasi rendah akan menghindari tugas dan siswa dengan efikasi diri tinggi akan lebih bersemangat, lebih gigih, dan berusaha lebih di dalam proses pembelajaran (Bandura, 
1997). Hal sebaliknya terjadi pada siswa yang memiliki efikasi diri rendah yaitu menunjukkan sikap menghindar terhadap beberapa tugas (Schunk dan Mullen, 2012).

Siswa yang memiliki efikasi diri yaitu percaya dengan kemampuannya, akan menunjukkan keterikatan perilaku pada proses pembelajaran (Pellas, 2014). Hasil penelitian juga menunjukkan keselarasan dengan pernyataan tersebut, yaitu banyaknya $(41,0 \%)$ subjek yang mendengarkan dengan seksama selama proses belajar, $41,0 \%$ subjek bekerja keras ketika memulai sesuatu hal baru, dan banyaknya $(43,9 \%)$ siswa berlatih keras di kelas .

Efikasi diri juga menjadikan siswa memiliki keterikatan emosi, keterikatan kognitif, dan keterikatan agentic. Hal ini dijelaskan oleh Reeve dan Tseng (2014), siswa dengan efikasi diri yang tinggi memiliki kepercayaan dalam mempelajari materi, sehingga menunjukkan reaksi positif saat belajar (keterikatan emosi), mampu menghubungkan pengalaman diri dengan materi yang sedang dipelajari (keterikatan kognitif), serta menjadikan siswa mampu mengajukan pendapat saat proses pembalajaran berlangsung, dan mejadikan siswa berkontribusi saat di kelas dengan mengajukan hal yang disukai dan tidak disukai (Reeve dan Tseng, 2014).

Sebuah penelitian memperkuat bahwa efikasi diri berperan terhadap keterikatan siswa. Penelitian tersebut dilakukan oleh Martin dan Kauffman (2015), menunjukkan hasil bahwa efikasi diri berperan terhadap keterikan emosi dan juga keterikatan sosial siswa. Martin dan Kauffman (2015) menjelaskan bahwa siswa dengan efikasi diri yang tinggi memunculkan ketertarikan dan menikmati proses belajar, sehingga menjadikan siswa mampu mengerjakan tugas bersama teman lainnya.

Hasil penelitian menunjukkan bahwa orientasi tujuan penguasaan berperan terhadap keterikatan siswa belajar bahasa
Inggris. Hal ini dapat dikaitkan dengan hasil penelitian yang menunjukkan tingginya orientasi tujuan penguasaan dan keterikatan siswa, yaitu orientasi tujuan penguasaan kategori tinggi sebanyak (65,9\%) dan keterikatan siswa kategori tinggi $(60,7 \%)$. Hal tersebut dikarenakan siswa dengan orientasi tujuan penguasaan memiliki pandangan baik terkait pembelajaran, usaha, dan kegagalan, yaitu menyadari bahwa belajar adalah proses dari usaha keras serta bertahan meski mengalami kemunduran (Ormrod, 2003).

Pendapat lain juga menjelaskan bahwa orientasi tujuan penguasaan berperan terhadap keterikatan siswa belajar bahasa Inggris. Hal ini dikarenakan siswa yang memiliki orientasi tujuan penguasaan menjadikan siswa memiliki keterikatan kognitif, emosional, dan perilaku yang sangat tinggi (Anderman \& Patrick, 2012). Keterikatan emosi siswa tinggi pada siswa yang memiliki orientasi tujuan penguasaan tinggi, ditunjukkan dengan perasaan positif siswa saat di kelas dan lebih termotivasi untuk mengikuti pelajaran di kelas (Ames, 1992). Siswa juga menunjukkan sikap positif terhadap tugas yang diberikan saat pelajaran berlangsung, khususnya pada tugas yang lebih menarik dan menantang (Ames dan archer, 1988). Hal lain yang membuktikan pengaruh orientasi tujuan penguasaan terhadap keterikatan emosi siswa yaitu kepuasaan pada diri siswa saat mengikuti pelajaran (Nolen dalam Ucar \& Sungur, 2017) dan mampu merespon dengan baik sebuah kegagalan saat proses belajar (Midgley, Kaplan, \& Middelton, 2001).

Siswa yang memiliki orientasi tujuan penguasaan yang tinggi juga menunjukkan keterikatan kognitif yang tinggi, hal ini dikarenakan siswa mampu melaksanakan strategi kognitif secara efektif yang ditunjukkan dengan elaborasi, metakognitif (perencanaan, pemantauan, dan regulasi) 
(Ames dan Archer 1998). Selain itu, pengaruh orientasi tujuan penguasan juga memengaruhi keterikatan perilaku siswa yang ditunjukkan dengan perilaku adaptif (Anderman \& Patrick, 2012) yang ditunjukkan dengan berusaha untuk menyelesaikan tugas (Wolters dalam Ucar dan Sungur, 2017) dan mencari bantuan untuk meminta penjelasan terkait materi yang diajarkan ( $\mathrm{Ng}$, 2014).

Hasil penelitian menunjukkan peran efikasi diri bahasa Inggris tidak seutuhnya menjadi perantara antara orientasi tujuan penguasaan dengan keterikan siswa belajar bahasa Inggris karena terjadi mediasi parsial. Mediasi parsial merupakan kondisi variabel independen ke dependen menurun namun tidak sama dengan nol dengan adanya peran mediator (Baron dan Kenny, 1986). Mediasi parsial diindikasi terjadi karena terdapat variabel mediator lainnya yang juga memengaruhi peran variabel Independen dan dependen (Baron dan Kenny, 1986).

Hasil penelitian tersebut tidak sesuai dengan pendapat Pintrich dan Schunk (1996) dan Bandura (1986, 1997). Pintrich dan Schunk (1996) bahwa orientasi tujuan penguasaan menjadikan siswa memiliki efikasi diri untuk mencapai tujuan penguasaan, sehingga siswa menjadi terikat pada proses pembelajaran. Efikasi diri berdasarkan teori kognitif sosial merupakan dasar perilaku yang memengaruhi keterikatan pada aktivitas, memengaruhi energi dan usaha untuk mencapai tujuan yang sudah ditetapkan, serta memengaruhi tingkat ketekunan saat menghadapi rintangan (Bandura, 1986, 1997).

Beberapa penelitian menunjukkan hasil yang serupa yaitu efikasi diri berperan sebagai mediator yang memediasi secara parsial. Penelitian oleh Vayre dan Vonthron (2017) menunjukkan bahwa efikasi diri akademik memediasi secara parsial antara dukungan, komunitas, dan keterikatan siswa. Penelitian yang dilakukan Celik
(2015) yaitu efikasi diri akademik memediasi secara parsial antara hubungan dukungan akademik dan personal growth initiative (PGI). Penelitian Dolzan, Sartori, Charkarhabi, dan Paola (2015) menunjukkan efikasi diri memediasi secara parsial antara keterikatan sekolah dengan perilaku beresiko. Berikut penjelasan terkait ketiga hasil penelitian tersebut yang mendukung hasil penelitian ini yaitu terkait efikasi diri sebagai mediator parsial.

Penelitian dilakukan oleh Vayre dan Vonthron (2017) terhadap 255 mahasiswa dengan pengajaran online, hasil penelitian menunjukkan bahwa dukungan sosial guru berperan terhadap keterikatan siswa, faktor komunitas berperan langsung terhadap keterikatan siswa, dan efikasi diri akademik memediasi secara parsial hubungan antara komunitas dan enthusiam engagement. Vayre dan Vorthon (2017) menyatakan bahwa hal ini menunjukkan pentingnya peran lingkungan yaitu khususnya komunitas dan dukungan terhadap keterikatan siswa karena berkaitan pada proses interaksi dengan teman dan guru yang mampu membantu meningkatkan pemahaman pada proses e-learning.

Oleh karenanya, merujuk pada hasil penelitian Vayre dan Vonthro (2017) dan mengaitkan pendekatan teori kognitif sosial (Bandura 1986, 1997) pada penelitian ini, dapat diindikasi terdapat peran lingkungan yang berdampak pada peran efikasi diri sebagai mediasi parsial pada hubungan antara orientasi tujuan penguasaan dan keterikatan siswa. Faktor lingkungan diantaranya contoh teladan, umpan balik, dan instruksi (Schunk, 1999). Hasil penelitian menunjukkan penilaian siswa terhadap lingkungan sebagai berikut. Sebanyak 39\% subjek menyatakan yakin bahwa sekolah memberikan pengajaran yang bagus dan 51,4\% menyatakan ragu. Sebanyak 38,2 \% subjek merasa yakin guru akan bersikap baik meski siswa tidak selalu 
mendapat nilai baik dan $43,4 \%$ menyatakan ragu.

Hasil penelitian yang dilakukan Celik (2015) juga menunjukkan hasil yang sama yaitu efikasi diri akademik memediasi secara parsial antara hubungan dukungan akademik dan personal growth initiative (PGI). Hal ini dijelaskan oleh Celik (2015) karena efikasi diri yang dimiliki memuculkan peran faktor lain yaitu motivasi akademik, kegigihan, sehingga dukungan akademik dapat beruhubungan langsung dan tidak langsung dengan PGI. Celik (2015) menyimpulkan bahwa dukungan akademik dan efikasi diri berperan penting terhadap PGI.

Hasil penelitian Dolzan, Sartori, Charkarhabi, dan Paola (2015) menunjukkan efikasi diri memediasi secara parsial antara keterikatan sekolah dengan perilaku beresiko. Hal ini dijelaskan pada penelitian tersebut bahwa efikasi diri merupakan faktor utama yang dapat mencegah perilaku beresiko meski memiliki keterikatan di sekolah. Hasil penelitian tersebut juga menjelaskan berdasarkan teori kognitif sosial bahwa orientasi tujuan penguasan dan efikasi diri bekerjasama untuk meningkatkan motivasi. Efikasi diri dijelaskan pada penelitian tersebut bahwa dapat memfasilitasi untuk siswa terikat di sekolah yang menjadikan siswa merasa sejahtera di sekolah sehingga menurunkan perilaku beresiko.

Oleh karenanya, serupa dari ketiga hasil penelitian tersebut dapat diungkapkan bahwa makna hasil mediasi parsial dari penelitian ini yaitu siswa yang berorientasi tujuan penguasaan menjadi terikat pada proses pembelajaran karena adanya efikasi diri bahasa Inggris yang baik. Selain itu, tanpa adanya efikasi diri pada siswa tetap menjadikan siswa terikat pada proses pembelajaran karena siswa tetap berorientasi tujuan penguasaan. Oleh karenanya dapat dikatakan bahwa efikasi diri bahasa Inggris dan orientasi tujuan penguasaan penting untuk dimiliki oleh siswa untuk menjadi terikat pada prose belajar bahasa Inggris.

Hasil uji tambahan menunjukkan bahwa siswa laki-laki lebih memiliki efikasi diri yang tinggi dibandingkan siswa perempuan. Hasil penelitian oleh Kiran dan Sungur (2012) pada siswa tingkat menengah menunjukkan tidak ada perbedaan efikasi diri antara laki-laki dan perempuan, tetapi ditemukan bahwa siswa perempuan lebih menanggapi sebuah pengalaman dengan melibatkan emosi. Penelitian oleh Britner dan Pajares (2006) menunjukkan bahwa perempuan lebih cemas, lebih stress, lebih depresi khusunya pada pelajaran ilmiah yang menjadikan efikasi diri perempuan lebih rendah dibandingkan laki-laki.

\section{Kesimpulan}

Penelitian ini membuktikan bahwa efikasi diri bahasa Inggris berperan sebagai mediator secara parsial antara orientasi tujuan penguasaan dengan keterikatan siswa belajar bahasa Inggris. Hal ini menunjukkan orientasi tujuan penguasaan yang secara langsung dan tidak langsung yaitu melalui perantara efikasi diri mampu memengaruhi keterikatan siswa dalam mempelajari bahasa Inggris. Orientasi tujuan penguasaan, efikasi diri bahasa Inggris, dan keterikatan siswa belajar bahasa Inggris cenderung tinggi. Efikasi diri siswa laki-laki lebih tinggi dibandingkan siswa perempuan.

Saran

Guru dan siswa untuk tetap mempertahankan tingginya keterikatan siswa dengan tetap memperhatikan efikasi diri bahasa Inggris dan membentuk pembelajaran yang beorientasi tujuan penguasaan. Guru dapat melakukan cara seperti yang dicontohkan oleh Ormrod 
(2003), yaitu membentuk kelompok dengan tujuan siswa dapat bekerja sama satu dengan yang lain. Siswa terus berlatih untuk mencoba dengan mencari tujuan dan manfaat yang didapat saat siswa mempelajarai materi, siswa tetap berusaha dan menghargai setiap perbaikan yang sudah dilakukan, menikmati setiap tugas yang diberikan guru. Saran bagi penelitian selanjutnya yaitu dapat melakukan penelitian pada sekolah yang memiliki karaktertistik berbeda dengan karakteristik penelitian ini yaitu sekolah swasta dan tidak terakreditasi A.

\section{Daftar Pustaka}

Abas, Z. W. (2015). Fostering learning in the 21st century through student engagement. International Journal for Educational Media and Technology, 9(1), 3-15.

Ames, C. (1992). Classrooms: Goals, structures, and student motivation. Journal of Educational Psychology, 84(3), 261-271. doi: 10.1037/0022$\underline{0663.84 .3 .261}$

Ames, C., \& Archer, J. (1988). Achievement goals in the classrooms: Student's learning strategies and motivation processes. Journal of Education Psychology, 80(3), 260-267. doi: 10.1037/0022-0663.80.3.260

Anderman, E. M., \& Patrick, H. (2012). Achievement goal theory, conceptualization of ability/intelligence, and classroom climate. In S. L. Christenson, A. L. Reschly, \& C. Wylie, Handbook of research on student engagement (pp. 173- 191). New York: Springer.

Bandura, A. (1986). Social foundations of thoughts and action a social cognitive theory. New Jersey: Prentice Hall, Inc.

Bandura, A. (1997). Self-efficacy the exercise of control. New York: W.H Freeman and Company.
Baron, R. M., \& Kenny, D. A. (1986). The Moderator-mediator variable distinction in social psychological research: Conceptual, strategies, and statistical considerations. Journal of Personality and Social Psychology, 51(6), 1173-1182. doi: 10.1037/0022$\underline{3514.51 .6 .1173}$

Baroody, A. E., Rimm-Kaufman, S. E., Larsen, R. A., \& Curby, T. W. (2016). A multi-method approach for describing the contributions of student. Learning and Individual Differences, 48, 54-60. doi: 10/1016/j/lindif.2016.02.012.

Britner, S. L., \& Pajares, F. (2006). Sources of science self-efficacy beliefs of middle school students. Journal of Research in Science Teaching, 43(5), 485-499. doi: 10.1002/tea.20131.

Celik, E. (2015). Mediating and moderatoring role of academic self efficacy in the relationship between student academic support an personal growth initiative. Australian Council of Educational Research, 24(2), 105-113. doi: $\underline{10.1177 / 1038416}$ 215583563.

Christenson, S. L., Reschly, A. L., \& Wylie, C. (2012). Handbook of research on student engagement. New York: Springer.

Dolzan, M., Sartori, R., Charkhabi, M., \& Paola, F. D. (2015). The effect of school engagement on health risk behaviours among high school students: testing the mediating role of self efficacy. Social and Behavioral Sciences, 205, 608-613. doi: 10.1016/ j.sbspro.2015.09.091

EPI, E. (2016). Indeks kecakapan Bahasa Inggris $E F$. Education First. Retrieved from http://www.ef.co.id/epi/downloads/. Exley, B. (2005). Learner characteristics of 'Asian' EFL students : exception to the 'Norm'. Proceedings Pleasure Passion Provocation. Joint National Conference 
AATE \& ALEA 2005, (pp. 1-16). Australia

Gerhardt, M. W., \& Brown, K. G. (2006). Individual differences in self efficacy development: the effects of goal orientation and affectivity. Learning and Individual Differences, 16, 43-59. doi: $10.1016 / j .1 i n d i f 2005.06 .006$.

Hsieh, P., Sullivan, J. R., \& Guerra, N. S. (2007). A closer look at college students. Journal of Advanced Academic, 18(3), 454-476.

Kiran, D., \& Sungur, S. (2012). Midle school students'science self-efficacy and its sources: Examination of gender differences. Journal of Science Education and Technology, 21(5), 619630. doi: 10.1007/s10956-011-9351-y.

Linnenbrink, E. A., \& Pintrich, P. R. (2003). The role of self efficacy beliefs in student engagement and learning in the classroom. Reading and Writting Quarterly, 19(2), 119-137. doi: 10.1080/10573560390143076.

Mahyuddin, R., Elias, H., Cheons, L. S., Muhamad, M. F., Noordin, N., \& Abdullah, M. C. (2006). The relationship between students' self efficacy and their english language achievement. Jurnal Pendidik dan Pendidikan, 21, 61-71.

Marcellino, M. (2008). English language teaching in Indonesia a continous challenge in education and cultural diversity. TEFLIN Journal, 19(1), 5769. doi: 10.15639/teflinjournal.v $\underline{19 i 1 / 57-69}$

Martin, D. P., \& Rimm-Kaufman, S. E. (2015). Do student self efficacy and teacherstudent interaction quality contribute to emotional and social engagement in fifth grade math? Journal of School Psychology, 53, 359373. doi: $10.1016 / j . j s p .2015 .07 .001$

Megawati, F. (2016). Kesulitan mahasiswa dalam mencapai pembelajaran bahasa Inggris secara efektif. Jurnal Pedagogia, 2(5), 147-156. doi: 10.21070/pedagogia.v5i2.246

Midgley, C., Kaplan, A., \& Middelton, M. (2001). Performance - approach goals: good for what, for whom, under what circumtances, and at what cost? Journal of Educational Psychology, 93(1), 77-86. doi: 10.1037/0022-0663.93.1.77

Mih, V., Mih, C., \& Dragos, V. (n.d.). Achievement goals and behavioral and emotion engagement as precursors of academic adjusthing. Social and Behavioral Sciences, 209, 329-336. doi: 10.1016/j.sbspro. 2015. 11.243.

$\mathrm{Ng}$, M. (2014). Self efficacy beliefs and ecademic help seeking behavior of chinese students. Journal of Educational Psychology, 4(66), 17-31.

Nichols, R. (2014). Motivating english language learners: an Indonesian case study. Master of Education Program Theses, 52.

Ormrod, J. E. (2003). Educational psychology developinh learner fourth edition. Ohio: Merrill Prentice Hall.

Pajares, F. (2002). Gender and perceived self efficacy in self regulated learning. Theory into Practice, 41(2), 116-125. doi: $10.1207 / s 15430421$ tip4102 8

Panjaitan, M. O. (2013). Analisis standar isi bahasa inggris SMP dan SMA. Jurnal Pendidikan dan Kebudayaan, 19(1), 140-155. doi: 10.24832\%2Fjpnk. $\underline{\mathrm{v} 19 \mathrm{i} 1.113}$

Pellas, N. (2014). The influence of computer self efficacy metacognitive self regulation and self esteem on student engagement in online learning programs: Evidence from virtual world of second life. Computers in Human Behavior, 35, 157170. doi: 10.1016/j.chb.2014.02.048. 
Pintrich, P. R., \& H. Schunk, D. (1996). Motivation in education. New Jersey: Prentice Hall.

Rahmawati, Moestadi, M. J., Widaryanto, B., Ekaningrum, T. N., Hikamuddin, E., Susetiyo, H., \& Rohayati, W. (2014). Laporan hasil ujian nasional tahun 2014. Jakarta: Pusat Penilaian Pendidikan - Balitbang Kemdikbud.

Reeve, J., \& Tseng, C.-M. (2011). Agency as a fourth aspect of students' engagement during learning activities. Contemporary Educational Psychology, 36, 257-267. doi: $10.1016 /$ j.cedpsych.2011.05.002

Safari. (2015). Ujian nasional sebagai cermin mutu pendidikan dan pemersatu bangsa. Jurnal Pendidikan dan Kebudayaan, 21(2), 101-113. doi: 10.24832\%2Fjpnk.v21i2.180

Schunk, D. H. (2012). Teori-teori pembelajaran: Perspektif pendidikan. Yogyakarta: Pustaka Pelajar.

Schunk, D. H., \& Mullen, C. A. (2012). Selfefficacy as an engaged learner. Dalam S. L. Christenson, A. L. Reschly, \& C. Wylie, Handbook of research on student engagement (hal. 219-235). New York: Springer.

Shin, J., Lee, Y.-k., \& Seo, e. (2017). The effects of feedback on students's achievement goals: Interaction between reference of comparison and regulatory focus. Learning and Instruction, 49, 21-31. doi: 10.1016/ j.learninstruc.2016.11.008
Simbolon, N. (2014). Pengaruh pendekatan pembelajaran dan kemampuan verbal terhadap kemampuan berbicara bahasa Inggris siswa SMA Negeri 14 dan 21 Medan. Cakrawala Pendidikan, 2, 225-235. doi: 10.21831/cp.v2i2.2149

Ucar, F. M., \& Sungur, S. (2017). The role of perceived classrom goal structures, self-efficacy.and engagement in student science achievement. Research in Science \& Technological Education, 35(2), 149-168. doi: 10.1080/02635143.2017.1278684.

Vayre, E., \& Vonthron, A.-M. (2017). Psychological engagement of students im distance and online learning: effects of self-efficacy and psychosocial processes. Journal of Educational Computing, 55(2), 197-218. doi: $10.1177 / 0735633116656849$.

Woolfolk, A. (2008). Educational psychology active learning edition. (H. P. Soetjipto, \& S. M. Soetjipto, Trans.) Boston: Pearson Education, Inc.

Zare, H., Rastegar, A., \& Hosseini, S. M. (2011). The relation among achievement goals and academic achievement in statistic: the mediating role of statistics anxiety and statistics self-efficacy. Social and Behavior Sciences, 30, 1166-1172. doi: 10.1016/j.sbspro.2011.10.227 